\title{
Artificial concerns. Effects of a commercial advertisement on modern health worries and sympathetic activation
}

\author{
FERENC KÖTELES* - ESZTER TARJÁN - TÍMEA BERKES \\ Institute of Health Promotion and Sport Sciences, \\ Eötvös Loránd University, Budapest, Hungary
}

(Received: 15 October 2015; accepted: 20 January 2016)

\begin{abstract}
Theoretical background: Many companies offer products that are claimed to protect against harmful environmental factors. Advertisements of such products are designed to maximize risk perception and worrying, which may have a negative impact on psychological functioning and health. Public worry about the harmful effects of various environmental factors may also be boosted.

Aim: To measure the impact of an advertising film on worrying and sympathetic activation.

Methods: 100 young adults completed questionnaires measuring constructs that were connected to modern health worries in past studies (somatosensory amplification, health anxiety, subjective somatic symptoms, beliefs about the validity of complementary and alternative medicine, holistic health beliefs, and spirituality). Participants were asked to watch an advertising film exaggerating the risks posed by electromagnetic radiation or a control film. Sympathetic activation (as assessed by heart rate) was measured before and after the intervention. Worrying (as assessed by the Radiation sub-scale of the Modern Health Worries Scale) was measured before and after the intervention, and three weeks later.

Results: Compared to the control film, the advertisement caused an acute increase in heart rate $(\mathrm{t}(98)=4.122, \mathrm{p}<.001)$. Concerning worrying, a mixed analysis of variance indicated a significant group $\times$ time interaction $(\mathrm{F}(2,98)=3.455 ; \mathrm{p}=.034)$. In the post hoc analysis, the control group showed no significant deviations from baseline. In the intervention group, however, significant $(\mathrm{p}<.05)$ differences were found from baseline at both follow-ups. Acute change in worrying was not connected to any assessed psychological construct (i.e., no effect modification was found).

Conclusions: Commercial advertisements of certain health protecting products can play a role in the generation and maintenance of modern health worries. From a broader point of view, such advertisements may contribute to both the social amplification of risk and possible development of a moral panic.
\end{abstract}

Keywords: risk perception, public health, modern health worries, moral panic

\footnotetext{
* Corresponding author: dr. Ferenc Köteles, Institute of Health Promotion and Sport Sciences, Eötvös Loránd University, Bogdánfy Ödön u. 10. H-1117 Budapest, Hungary. E-mail: koteles. ferenc@ppk.elte.hu
} 


\section{Introduction}

Worries about possible harmful side effects of modern technologies (modern health worries, MHWs) have shown a considerable increase in the last decades (Petrie et al., 2001; Petrie \& Wessely, 2002). According to empirical results, objective threat posed by typical subjects of such worries (particularly in the case of electromagnetic fields, EMFs) is often minimal or even questionable (ICNIRP, 2003, 2010; Röösli, Frei, Mohler, \& Hug, 2010). From an epidemiological point of view, these risks are practically negligible compared to the effects of other well-known risk factors (overweight, sedentary life style, etc.). Consequently, feelings of vulnerability and perceived risk connected to these factors are exaggerated, and might be harmful in themselves (Litmanen \& Tuikkanen, 2008; Petrie et al., 2001; Petrie \& Wessely, 2002).

In the scientific literature, two possible sources of MHWs have been proposed and investigated to date. First, although the actual impact of media on risk perception generally is still an open question (Vilella-Vila \& CostaFont, 2008; Wahlberg \& Sjoberg, 2000), mass media reports presenting and exaggerating the threat posed by factors of modernity are often mentioned (Freyler, Köhegyi, Köteles, Kökönyei, \& Bárdos, 2013; Petrie et al., 2001; Petrie \& Wessely, 2002; Witthöft \& Rubin, 2013). These reports, usually based on individual stories and case studies, present beliefs about seemingly obvious connections between certain environmental factors and symptoms or diseases, and don't attempt to give a balanced picture on the phenomenon in question (Claassen, Smid, Woudenberg, \& Timmermans, 2012; Eldridge-Thomas \& Rubin, 2013). Although there can be a shift in the media towards educating and informing people (Elvers, Jandrig, Grummich, \& Tannert, 2009), media coverage still focuses on the negative aspects of modern technology and its potential health risks (Claassen et al., 2012; Elvers et al., 2009). According to our current knowledge, there might be individual differences in sensitivity to these influences: MHWs were found to be associated with certain trait-like personality characteristics (somatosensory amplification - SSA, somatization tendency, health anxiety - HA, spirituality, holistic thinking style) in cross-sectional studies (Freyler et al., 2013; Köteles \& Simor, 2014a, 2014b; Köteles, Szemerszky, Freyler, \& Bárdos, 2011), and it was also claimed that these characteristics could increase vulnerability to MHWs (Köteles \& Simor, 2014b; Köteles, Szemerszky, et al., 2011). Interestingly, people who prefer complementary and alternative medicine (CAM) to conventional medicine also showed higher levels of MHWs in several cross-sectional studies (Furnham, 2007; Jeswani \& Furnham, 2010; Köteles, Bárány, Varsányi, \& Bárdos, 2012; Köteles \& Simor, 2014b; Strait \& Furnham, 2012). 
Beyond media influences, empirical findings support the idea that family as the primary agent of socialization can transmit parental MHWs to the next generation (Köteles, Freyler, Kökönyei, \& Bárdos, 2015). Although no empirical studies have been carried out to date, role of other social agents (e.g. peer groups, social media) in the transmission of such worries is also presumable.

While socialization processes take place more or less automatically, the first factor (mass media reports) is often designed to increase emotional impact (i.e., the "wow-factor"). Beyond these two, a further source of MHW related information exists, namely advertisements of companies manufacturing and selling products that are claimed to protect against such harmful factors. In this case, the information (more precisely: the message) is professionally elaborated to manipulate people's reaction and maximize negative impact. It is usually claimed that these harmful effects are (1) scientifically proven but kept secret by evil profit oriented companies for financial reasons, and (2) more serious than it is reported in the scientific literature (Blushield, n.d.; Hamoni, n.d.; Sensory Perspective, n.d.; Swiss Harmony, n.d.). Beyond reasoning, these advertisements attempt to make the emotional and cognitive reactions more intense by emphasizing the message with alerting visual and sound effects, or by mentioning that children and close relatives might also be involved.

The MHW phenomenon is usually investigated at the level of the individuals; however, a sociological perspective might also be helpful in the understanding of the complex interactions involved in the generation and maintenance of these worries. For example, the Social Amplification of Risk Framework suggests that information about potential hazards interacts with psychological, social, institutional and cultural processes, which leads to the amplification or attenuation of public responses to the risk (Kasperson, Kasperson, Pidgeon, \& Slovic, 2003; Kasperson et al., 1988). Commercial advertisements may represent a factor that is intentionally designed to elevate risk perception, feeling of vulnerability, and worrying; therefore, its psychological and societal impact might be more serious than that of media reports or family influences. From the viewpoint of MHW-related advertisements, the phenomenon can also be regarded as an attempt to give rise (or least contribute) to a moral panic (i.e., the process of arousing social concern over an issue that poses a threat on the welfare of society). Moral panic has distinct and well-described characteristics as (1) intense concern over an issue, (2) hostility towards the group that is believed to cause the issue in question, (3) a widespread consensus on the negative impact of the accused group, (4) disproportionality (concerns and actions are exaggerated compared to the actual threat), and (5) volatility (temporal instability) (Goode \& 
Ben-Yehuda, 2009). It is also well-known from the literature of moral panic that reporting the facts in the media is enough to trigger concern and anxiety (Cohen, 1972); consequently, impact of advertisements can be more intense and harmful.

In the experiment reported here, young adults were exposed to such an alerting advertisement, and changes in worrying and sympathetic activation were measured. The first aim of the study (Hypothesis 1) was replicating previous results on the connections between MHWs and negative affect (NA), somatosensory amplification (SSA), health anxiety (HA), symptoms, CAM orientation, holistic health beliefs, and spirituality. Second (Hypothesis 2), it was hypothesized that an advertisement exaggerating the threats posed by EMFs causes an increase in worrying and also activates the sympathetic nervous system. Third (Hypothesis 3), it was expected that individuals with higher levels of NA, SSAS HA, somatic symptoms, CAM orientation, holistic health beliefs, or spirituality would respond to the message with disproportionately increased worrying. Design of the study is presented in Figure 1.

advertisement / control film

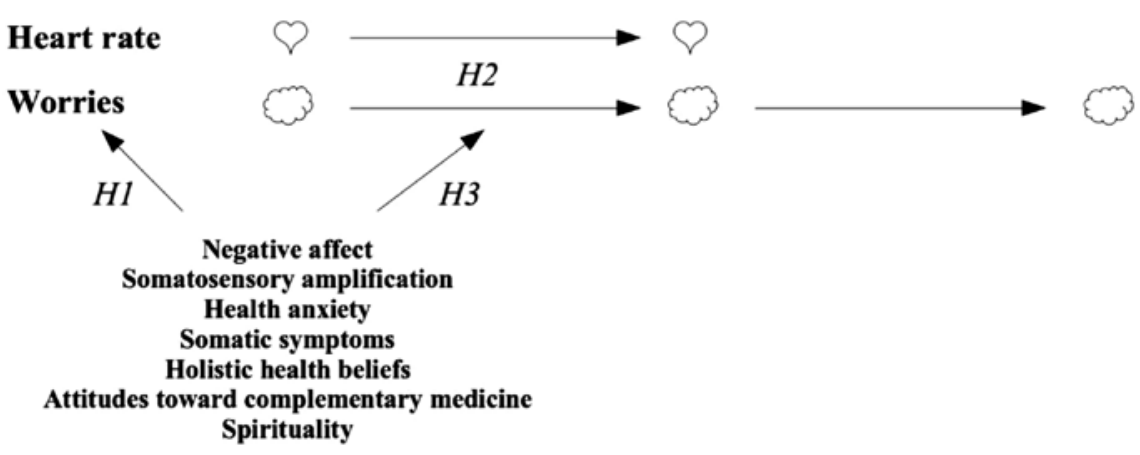

Measurements: $\quad$ tl (baseline)

t2 (post-intervention)

t3 (three weeks later)

Figure 1. Design and hypotheses of the study.

Assessed variables are marked in bold. It was hypothesized that (H1) baseline self-report characteristics would be connected to modern health worries,

(H2) advertisement would increase worrying and heart rate, and (H3) baseline characteristics would moderate the effect of advertisement on worrying (effect modification) 


\section{Method}

\subsection{Participants}

Based on a power analysis for the correlation analyses ( $\alpha=0.05$ (one-tailed), $\beta=0.90$, and $r=0.30$ ), a target sample size of $98-100$ was determined. Participants were undergraduate university students $(\mathrm{N}=100$; mean of age: 20.6 years, $S D=1.01$ years; $72 \%$ females) who received partial credit for their participation. Seven participants dropped out from the study due to incomplete self-report or physiological data. The research was approved by the Research Ethical Committee of the Faculty of Pedagogy and Psychology of the Eötvös Loránd University (Nr. 2012/100), all participants signed a consent form before the experiment.

\subsection{Measures}

Modern Health Worries Scale (MHWS) (Petrie et al., 2001) is a 25-item scale that measures people's concerns of modernity affecting their health on a 5-point Likert scale (1: no concern, 5: extreme concern). Scores of the MHWS range from 25 to 125 (higher scores indicate more worries), and although no pathological threshold has been determined to date, it demonstrated a good discriminative power between patients with Idiopathic Environmental Intolerance (IEI) and patients with other psychiatric diseases (Bailer, Witthöft, \& Rist, 2008). Similarly to previous results (Köteles \& Simor, 2014a; Köteles, Szemerszky, et al., 2011), the Hungarian version of the scale showed a high internal consistency (Cronbach's alpha $=0.94)$ in the current study.

MHWS Radiation subscale (MHWS Radiation) is a 3-item subscale of the MHWS assessing worries about the effects of electromagnetic radiation (e.g., from high frequency power lines or mobile phone towers). Items are rated on a 5-point Likert scale (1: no concern, 5: extreme concern). Similarly to the MHWS total score, the MHWS Radiation score (ranging from 3 to 15, higher scores refer to more worries) is not used for diagnostic purposes; however, it discriminated well between individuals with IEI attributed to electromagnetic fields (aka electrosensitivity or electromagnetic hypersensitivity) and healthy controls in several experimental studies (Köteles et al., 2013; Szemerszky, Gubányi, Árvai, Dömötör, \& Köteles, 2015). Its internal consistency was good (between 0.84 and 0.88 ) in all three administrations of the present study.

Somatosensory Amplification Scale (SSAS) is a 10-item scale that measures the tendency to experience a somatic sensation as intense, noxious, and dis- 
turbing on a 5-point Likert scale from not at all (1) to extremely (5) (Barsky, Wyshak, \& Klerman, 1990). Total score of the SSAS ranges from 10 to 50, higher scores indicate higher levels of amplification tendency. Higher levels of somatosensory amplification were connected to clinical hypochondriasis in empirical studies (Barsky \& Wyshak, 1990; Haenen, Schmidi, Schoenmakers, \& van den Hout, 1997; Speckens, Spinhoven, Sloekers, Bolk, \& van Hemert, 1996; Wyshak, Barsky, \& Klerman, 1991); however, it is not considered a diagnostic instrument. The Hungarian version proved to be valid and psychometrically sound in previous studies (Köteles et al., 2009, 2012; Köteles, Szemerszky, et al., 2011), however, its Cronbach's alfa coefficient was low (0.59) in the present study.

Negative affect (NA) was measured using the 5-item version of the Positive and Negative Affect Schedule (PANAS) (Gyollai, Simor, Köteles, \& Demetrovics, 2011; Thompson, 2007). The negative affect (NA) scale measures the general dimension of subjective distress and unpleasurable engagement that subsumes a variety of aversive mood states (e.g. guilt, fear, nervousness) on a 5-point Likert scale (1: not at all, 5: very much). Total score ranges from 5 to 25 (Watson, Clark, \& Tellegen, 1988), higher scores indicate higher levels of negative affect. Cronbach's alpha coefficient of the scale was 0.73 in the study.

Short Health Anxiety Inventory (SHAI) (Salkovskis, Rimes, Warwick, \& Clark, 2002) was used to measure health anxiety. The SHAI contains 18 items that assess health anxiety independently of actual physical health status on a 4-point scale. Total score of the SHAI ranges from 18 to 72 (higher scores show more health anxiety), a cut-off score of 45 provided the best balance between sensitivity and specificity in clinical context (Abramowitz, Olatunji, \& Deacon, 2007). The Hungarian version (Köteles, Simor, \& Bárdos, 2011) administered in the study showed good internal consistency (0.80).

Subjective somatic symptoms were assessed via the Patient Health Questionnaire Somatic Symptom Severity Scale (PHQ-15). This is a 15-item scale designed to measure the prevalence of the most common body symptoms (e.g. headache, nausea, etc.) experienced in the last four weeks on a 3-point Likert scale (1: not bothered at all, 3: bothered a lot), higher scores indicate more and/or more disturbing symptoms (Kroenke, Spitzer, \& Williams, 2002). It covers 14 of the 15 most prevalent DSM-IV somatisation disorder symptoms. Total score ranges from 15 to 45; scores of 20, 25, and 30 represents cut-off points for low, medium, and high somatic symptom severity, respectively (Kroenke et al., 2002). Its internal consistency was acceptable $(0.68)$ in the present study. 
Spiritual Connection Questionnaire Short Version (SCQ-14) (Wheeler \& Hyland, 2008) assesses experience and beliefs of spiritual connection, an aspect of spirituality that is consistent with religious and non-religious interpretations of spirituality on a 7-point Likert scale (1: strongly disagree, 7: strongly agree), with a total score range of 14 to 98 . Higher scores refer to higher levels of spirituality. The scale showed excellent internal consistency (0.92) in the current sample.

The Holistic Complementary and Alternative Medicine Questionnaire (HCAMQ) (Hyland, Lewith, \& Westoby, 2003) consists of two scales. The 5-item Holistic Health $(\mathrm{HH})$ scale measures beliefs about holistic health, while the other 5-item scale (CAM) assesses beliefs about the validity of complementary and alternative medicine on a 6-point Likert scale (1: strongly agree, 6: strongly disagree) (Köteles, 2014). Total score ranges from 6 to 30 in both cases. Higher scores indicate higher levels of holistic health beliefs and stronger beliefs in CAM methods, respectively. Internal consistency of both scales was acceptable ( 0.73 and 0.75 , respectively) in the current study.

Heart rate recording: The Polar system (Polar RS- 400 watches with chest straps and transmitters) was used to monitor and record participants' heart rate $(\mathrm{HR})$ during the experiment. After the experimental sessions, recordings were downloaded to a computer and were analyzed by the Polar ProTrainer 5 software. HR was calculated for two periods of time: for a oneminute baseline and for the last 5 minutes of the presented film.

\subsection{Procedure}

On the day before the experiment (t1), participants were asked to complete all questionnaires on-line. The experiment was carried out in groups of 4-6 individuals. Upon arrival, participants were equipped with the Polar heart monitoring system (chest strap, transmitter, and watch) and the physiological recording started. Following the recording of a one-minute baseline in resting conditions, they were shown a 10-minute film. The groups were randomly assigned to one of two conditions. The intervention group $(\mathrm{N}=49)$ watched an advertisement of a company offering products that are claimed to protect against "electrosmog" or "electropollution". The film describes electromagnetic radiation emitted by various sources (e.g., household devices, power lines, mobile phones) as particularly harmful to human health. Claimed harmful effects of electromagnetic radiation are (mistakenly) connected and compared to those of radioactivity, lead poisoning 
from paints, smoking, pesticides, food additives, air pollution, etc. It is told that cell phone companies hired a highly respected public health scientist to prove that their devices are harmless. However, the researcher found a close connection between cell phone use and brain tumors, which was kept secret by companies and even government agencies. In summary, typical characteristics of a moral panic are included. Moreover, the film also presents the radiation visually, through the examples of children and adolescents using mobile phones, housewives using household devices, etc. The advertisement was originally downloaded from the web page of the company. Subsequently, it was removed from the page, however, it is still available by the authors upon request. The control group $(\mathrm{N}=51)$ was presented with a 10-minute part of a nature documentary (Animals Are Beautiful People). Directly after watching the film (t2), participants completed the MHWS, then the physiological recording was stopped, and the Polar system was removed. Participants were asked to fill out the MHWS once again 3 weeks later on-line (t3). After finishing the whole procedure, participants were debriefed and received up-to-date, scientifically accurate information on the risks posed by electromagnetic fields.

\subsection{Statistical analysis}

Obtained data was analyzed using the SPSS v20 software. Applied parametric or non-parametric statistical methods were chosen based on the results of normality analysis (Kolmogorov-Smirnov tests). Equality of gender ratio in the two groups was checked by chi-square test, mean ages were compared by Mann-Whitney $U$ test. Baseline questionnaire scores of the two groups were compared using Student's $t$-test or Mann-Whitney $U$ test. Connections among assessed variables at baseline (Hypothesis 1) were checked using Pearson correlation or Spearman correlation. As seven independent analyses were carried out which might lead to the accumulation of Type I statistical errors, accepted level of significance was set to $0.05 / 7=$ 0.007 (Bonferroni correction). Changes in MHW Radiation scores (Hypothesis 2) over time were checked using a mixed (2 groups $x 3$ measurements) analysis of variance (ANOVA) with Bonferroni corrected post hoc tests. To test changes in HR caused by the intervention (Hypothesis 2), baseline HR values were subtracted from the $t 2$ values, and mean changes in the two groups were compared using an independent samples t-test. Moderating effect (effect modification) of assessed psychological variables on the intervention (Hypothesis 3) was checked using separate multiple linear re- 
gression analyses (accepted level of significance was adjusted using the Bonferroni correction). For example, in the case of negative affect, NA score was centered (i.e., mean calculated for the whole sample were subtracted from the individual NA score for each participant), then an interaction term with group affiliation (control vs. intervention) was calculated by multiplying the two variables. Finally, a linear regression analysis was carried out with MHW Radiation score at $\mathrm{t} 2$ as dependent variable, and MHW Radiation score at $\mathrm{t} 1$, centered NA score, group affiliation, and the interaction term as independent variables.

\section{Results}

Descriptive statistics of the assessed variables in the two groups are presented in Table 1. No baseline differences between the two groups in terms of gender ratio $\left(\chi^{2}(1)=0.103, p=.748\right)$, age (Mann-Whitney $U=1163.5, p=$ $.536)$, and any assessed variables were found (for details, see Table 1).

MHWs assessed at baseline showed significant, positive, moderate linear associations with somatosensory amplification (SSAS; $\mathrm{r}=.37, \mathrm{p}<.001$ ), health anxiety (HA; $\mathrm{r}=.35, \mathrm{p}<.001)$, beliefs about the validity of complementary and alternative medicine $(\mathrm{CAM} ; \mathrm{r}=.40, \mathrm{p}<.001)$, and spirituality (SCQ-14; $\mathrm{r}=.36, \mathrm{p}<.001$ ), but not associated significantly with negative affect $\left(N A ; r_{s}=.09, p=.206\right)$, somatic symptoms (PHQ-15; $r=.20, p=.046$ ), and holistic health beliefs $(\mathrm{HH} ; \mathrm{r}=.17, \mathrm{p}=.083)$.

The mixed ANOVA investigating changes in MHW Radiation score revealed a significant time main effect $\left(\mathrm{F}(2,98)=9.584 ; \mathrm{p}<.001 ;\right.$ partial $\rho^{2}=$ $0.089)$, a non-significant group main effect $(\mathrm{F}(1,98)=3.537 ; \mathrm{p}=.063$; partial $\left.\rho^{2}=0.035\right)$, and a significant group $\times$ time interaction $(\mathrm{F}(2,98)=3.455 ; \mathrm{p}=$ .034 ; partial $\left.\rho^{2}=0.034\right)$. According to the results of the post hoc analysis, there were no significant longitudinal changes in the control group. In the intervention group, significant differences between $t 1$ and $t 2$ scores $(p<$ $.001)$, and $t 1$ and $t 3$ scores $(p<.05)$ were found. However, the difference between $\mathrm{t} 2$ and $\mathrm{t} 3$ was only marginally significant $(\mathrm{p}=.076)$.

A significant difference between the intervention and the control group in change in heart rate $(\mathrm{M}=1.37, \mathrm{SD}=3.81$, and $\mathrm{M}=-3.20, \mathrm{SD}=6.79$, respectively; $\mathrm{t}(98)=4.122, \mathrm{p}<.001)$ was found. 
Table 1. Descriptive statistics of the assessed physiological and psychological variables, and results of baseline comparisons (Student's $t$-tests and Mann-Whitney

$U$ test) of the two groups (results of post-intervention $(\mathrm{t} 2, \mathrm{t} 3)$ comparisons are discussed in the text)

\begin{tabular}{|c|c|c|c|}
\hline Variables & $\begin{array}{c}\text { Intervention group } \\
(\mathrm{N}=49) \\
\text { Mean (SD) }\end{array}$ & $\begin{array}{c}\text { Control group } \\
(\mathrm{N}=51) \\
\text { Mean (SD) }\end{array}$ & $\begin{array}{l}\text { Group-level } \\
\text { differences }\end{array}$ \\
\hline Resting heart rate $(\mathrm{t} 1)$ & $72.7(10.72)$ & $72.3(7.40)$ & $\begin{array}{c}t(98)=0.261 \\
(p=.794)\end{array}$ \\
\hline Post-intervention heart rate (t2) & $74.1(10.05)$ & $69.1(9.14)$ & - \\
\hline Negative affect (NA) & $8.90(3.37)$ & $8.71(3.00)$ & $\begin{array}{c}t(98)=0.301 \\
(p=.764)\end{array}$ \\
\hline $\begin{array}{l}\text { Somatosensory amplification } \\
\text { (SSAS) }\end{array}$ & $28.65(4.76)$ & $27.53(4.57)$ & $\begin{array}{c}t(98)=1.205 \\
(p=.231)\end{array}$ \\
\hline Health anxiety (HA) & $34.84(5.65)$ & $33.08(6.42)$ & $\begin{array}{c}t(98)=1.451 \\
(p=.150)\end{array}$ \\
\hline Subjective symptoms (PHQ-15) & $21.67(3.84)$ & $21.04(3.74)$ & $\begin{array}{c}t(98)=0.837 \\
(p=.405)\end{array}$ \\
\hline $\begin{array}{l}\text { Modern health worries } \\
\text { (MHWS) }\end{array}$ & $45.78(13.87)$ & $45.77(16.32)$ & $\begin{array}{c}t(98)=0.002 \\
(p=.998)\end{array}$ \\
\hline MHWS Radiation subscale (t1) & $36.87(16.84)$ & $34.51(17.72)$ & $\begin{array}{l}U=1123.0 \\
(p=.371)\end{array}$ \\
\hline MHWS Radiation subscale (t2) & $47.48(18.79)$ & $37.12(18.58)$ & - \\
\hline MHWS Radiation subscale (t3) & $42.99(15.64)$ & $38.69(18.04)$ & - \\
\hline $\begin{array}{l}\text { Beliefs about the validity of } \\
\text { complementary and alternative } \\
\text { medicine (CAM) }\end{array}$ & $20.71(3.88)$ & $19.71(5.09)$ & $\begin{array}{c}t(98)=1.111 \\
(p=.269)\end{array}$ \\
\hline Holistic health beliefs $(\mathrm{HH})$ & $26.59(3.08)$ & $26.04(3.17)$ & $\begin{array}{c}t(98)=0.885 \\
(p=.379)\end{array}$ \\
\hline Spirituality (SCQ-14) & $55.94(18.00)$ & $51.59(18.53)$ & $\begin{array}{c}\mathrm{t}(98)=1.190 \\
(\mathrm{p}=.237)\end{array}$ \\
\hline
\end{tabular}

Results of effect modification analyses were presented in Table 2. In summary, all regression equations were statistically significant $(\mathrm{p}<.001)$, explaining $42-46 \%$ of the total variance of MHW Radiation score at $t 2$. In contrast, none of the interaction terms was significant, indicating that the assessed psychological variables had no impact on the change of the MHW Radiation score. 
Table 2. Results of the regression analyses investigating possible moderating effects of the respective variables on the change in MHW Radiation score from $\mathrm{t} 1$ to $\mathrm{t} 2$

\begin{tabular}{|l|c|c|c|}
\hline \multicolumn{1}{|c|}{ Variables } & \multicolumn{1}{|c|}{$\begin{array}{c}\mathbf{R}^{2} \\
(\mathbf{p})\end{array}$} & $\begin{array}{c}\text { Intervention } \\
\mathbf{e f f e c t :} \\
\boldsymbol{\beta}(\mathbf{p})\end{array}$ & $\begin{array}{c}\text { Variable } \times \text { intervention } \\
\text { interaction: } \\
\boldsymbol{\beta}(\mathbf{p})\end{array}$ \\
\hline Negative affect (NA) & $\begin{array}{c}0.436 \\
(\mathrm{p}<.001)\end{array}$ & $\begin{array}{c}0.225 \\
(\mathrm{p}=.004)\end{array}$ & $\begin{array}{c}-0.015 \\
(\mathrm{p}=.894)\end{array}$ \\
\hline $\begin{array}{l}\text { Somatosensory amplification } \\
\text { (SSAS) }\end{array}$ & $\begin{array}{c}0.417 \\
(\mathrm{p}<.001)\end{array}$ & $\begin{array}{c}0.226 \\
(\mathrm{p}=.005)\end{array}$ & $\begin{array}{c}-0.043 \\
(\mathrm{p}=.707)\end{array}$ \\
\hline Health anxiety (HA) & $\begin{array}{c}0.456 \\
(\mathrm{p}<.001)\end{array}$ & $\begin{array}{c}0.202 \\
(\mathrm{p}=.010)\end{array}$ & $\begin{array}{c}-0.038 \\
(\mathrm{p}=.706)\end{array}$ \\
\hline $\begin{array}{l}\text { Subjective symptoms } \\
\text { (PHQ-15) }\end{array}$ & $\begin{array}{c}0.457 \\
(\mathrm{p}<.001)\end{array}$ & $\begin{array}{c}0.216 \\
(\mathrm{p}=.005)\end{array}$ & $\begin{array}{c}0.184 \\
(\mathrm{p}=.090)\end{array}$ \\
\hline $\begin{array}{l}\text { Beliefs about the validity of } \\
\text { complementary and } \\
\text { alternative medicine (CAM) }\end{array}$ & $\begin{array}{c}0.418 \\
(\mathrm{p}<.001)\end{array}$ & $\begin{array}{c}0.225 \\
(\mathrm{p}=.005)\end{array}$ & $\begin{array}{c}0.042 \\
(\mathrm{p}=.667)\end{array}$ \\
\hline Holistic health beliefs (HH) & $\begin{array}{c}0.417 \\
(\mathrm{p}<.001)\end{array}$ & $\begin{array}{c}0.233 \\
(\mathrm{p}=.004)\end{array}$ & $\begin{array}{c}-0.041 \\
(\mathrm{p}=.707)\end{array}$ \\
\hline Spirituality (SCQ-14) & $\begin{array}{c}0.421 \\
(\mathrm{p}<.001)\end{array}$ & $\begin{array}{c}0.221 \\
(\mathrm{p}=.006)\end{array}$ & $\begin{array}{c}0.053 \\
(\mathrm{p}=.625)\end{array}$ \\
\hline
\end{tabular}

\section{Discussion}

In an experimental study with the participation of young healthy individuals, modern health worries showed medium level connections to somatosensory amplification, health anxiety, beliefs about the validity of complementary and alternative medicine, and spirituality. Compared to a neutral film, watching an advertisement that presents the risks of electromagnetic radiation in an exaggerated form caused higher levels of sympathetic activation (as assessed by heart rate) and worrying. The latter change was not connected to any assessed psychological variable; however, it was still measurable three weeks later.

With the exception of holistic health beliefs and somatic symptoms, previous findings on the connections between MHWs and illness-related (i.e., SSAS, HA) and holistic thinking style related (spirituality, beliefs about the validity of CAM) constructs were replicated in the current study (Hypothesis 1). Surprisingly, although these constructs were proposed to be possible "psychological risk factors" of MHWs (Köteles \& Simor, 2014a, 
2014b; Köteles, Szemerszky, et al., 2011), none of them predicted the change in worries triggered by the advertisement (Hypothesis 3). One possible explanation for this finding is that the advertisement in the experimental situation caused a ceiling effect in worrying, which suppressed the sensitizing effects of the above mentioned variables. Alternatively, the psychological risk factor hypothesis should be rejected, and a proactive information seeking effect (i.e., these characteristics make individuals more prone to seek out and pay attention to MHW-related information) or a reverse causal relationship (i.e., increased worrying facilitates holistic thinking style which in turn gives rise to illness-related concerns) should be hypothesized.

The MHW phenomenon can be described and understood as a specific set of cognitive biases, i.e. systematic distortions in the representation of reality and deviations from rational thinking. Once one adopted MHWs, information that is in accordance with one's belief system will be preferred and elaborated (confirmation bias). Belief perseverance bias inhibits a change in the belief system even in the presence of contradicting information (e.g., scientific reports on the objective risks). Moreover, availability and accessibility of MHW-related information will be increased due to rumination about environmental risk factors and proactive information seeking, respectively. Dual-process information processing theories, e.g., the Cognitive-Experiential Theory (CET) of Epstein (Epstein, 2014), are not only able to incorporate the aforementioned biases, but can also shed light on the background of the connections between MHWs and holistic thinking style, spirituality, and CAM preference (Köteles \& Simor, 2014b; Köteles, Simor, Czető, Sárog, \& Szemerszky, n.d.). From this point of view, the MHW phenomenon can be considered as an over-generalization of perceived risks from different sources posing very different objective risks. For example, concerning electromagnetic radiation, possible effects and risks of household electricity with a frequency of $50 / 60 \mathrm{~Hz}$ cannot be compared to those of mobile phones operating at the frequency domain of $10^{8}-10^{9} \mathrm{~Hz}$, or the higher UV and X-rays $\left(10^{16}-10^{20} \mathrm{~Hz}\right)$ (Repacholi, 2012). In terms of objective risk, the latter category (ionizing domain) is clearly dangerous (i.e., mutagenic). As for the non-ionizing domain, however, WHO concluded that current scientific evidence does not confirm the existence of any health consequences from exposure to low level electromagnetic fields (WHO, 2006, 2007, 2014). Still, risks of electromagnetic radiation and those of modern technologies in general are represented as a whole in people's mind, which is clearly indicated by the usually high internal consistency values of the MHW Radiation subscale ( 0.84 and 0.88 in the current study) and the MHW scale (0.94 in the current study) (Köteles \& Simor, 2014a; Köteles et al., n.d.).

This is not to say, of course, that MHWs are completely erroneous or illusory; harmful effects of ultraviolet radiation, X-rays, or air pollution can- 
not be questioned, and objective risks are difficult to estimate for many environmental agents. However, perceived health risks, compared to risks posed by other factors (e.g., smoking, alcohol consumption, sedentary lifestyle) are exaggerated and overgeneralized based on a common feature (modernity), which is not necessarily harmful in itself.

Previous research showed that assumed presence of an EMF (in more general terms, the perceived presence of a risk factor) increases worrying and symptom perception (Köteles et al., 2013; Rubin, Hillert, Nieto-Hernandez, van Rongen, \& Oftedal, 2011; Rubin, Nieto-Hernandez, \& Wessely, 2010; Szemerszky, Köteles, Lihi, \& Bárdos, 2010; Witthöft \& Rubin, 2013). The findings of the present study indicate that no actual threat is necessary for sensitization - even a negative message intentionally designed to increase risk perception is able (1) to increase worrying and (2) evoke physiological changes in the short run. After one single message, these negative changes might disappear over time; however, they may become prolonged following the reception of multiple messages (e.g., in an environment that is preoccupied with such concerns). As commercials are broadcast on a regular basis, this multiple exposure may have longer-lasting effects on viewers' risk perception, which in turn can increase public concern about the possible negative effects of EMFs. In summary, commercial advertisements of certain health protecting products represent a factor that may have a considerable contribution to the social amplification of risk.

Concerning mass media reports, a better cooperation between scientists and journalists was recommended to provide the public with a more balanced and scientifically valid picture on the effects of modern environmental factors (Eldridge-Thomas \& Rubin, 2013). In the case of commercial advertisements, this is certainly not sufficient, as protection of consumers from buying devices and gadgets that are both unnecessary and worthless is only one aspect of the phenomenon. MHWs were connected to more subjective somatic symptoms, depression, sick-leave, and a worse perceived health status and quality of life in cross-sectional studies (Filipkowski et al., 2010; Indregard, Ihlebæk, \& Eriksen, 2013; Ozakinci, Boratav, \& Mora, 2011; Rief et al., 2012), and also predicted future visits to the general practitioner in a longitudinal research (Andersen \& Jensen, 2012). Consequently, all possible communicational and legal steps should be taken to protect people from the negative health related effects of these seemingly protective messages.

The current study was carried out with the participation of university students, which limits generalizability (external validity) of the findings. On the other hand, life of this population is characterized by the intense use of various electric devices, which also means that they might be more resistant to messages communicating the risks posed by these devices than other individuals. In this case, harmful effects of similar commercial advertise- 
ments in the general population may be even more serious than those found in the present study. Moreover, the use of a nature documentary as control condition is also problematic; for example, although HR of the intervention group showed a significant increase compared to the control group, it is also possible that the relaxing effect of the nature documentary caused the difference. In future studies, films presenting objective (scientific) information on MHWs should be chosen for this purpose. Finally, personality characteristics that may influence general sensibility to advertisements (e.g., conformity, suggestibility, or susceptibility to advertising) should have been assessed and controlled for.

\section{Conclusion}

Commercial advertisements of certain health protecting products may play a role in the generation and maintenance of modern health worries, thus they might be more harmful than the factors the products are claimed to protect against. From a broader point of view, such advertisements may contribute to the social amplification of risk and even a moral panic.

\section{References}

Abramowitz, J.S., Olatunji, B.O., \& Deacon, B.J. (2007). Health anxiety, hypochondriasis, and the anxiety disorders. Behavior Therapy, 38(1), 86-94.

Andersen, J.H., \& Jensen, J.C. (2012). Modern health worries and visits to the general practitioner in a general population sample: An 18 month follow-up study. Journal of Psychosomatic Research, 73(4), 264-267.

Bailer, J., Witthöft, M., \& Rist, F. (2008). Modern health worries and idiopathic environmental intolerance. Journal of Psychosomatic Research, 65(5), 425-433.

Barsky, A.J., \& Wyshak, G. (1990). Hypochondriasis and somatosensory amplification. The British Journal of Psychiatry, 157, 404-409.

Barsky, A.J., Wyshak, G., \& Klerman, G.L. (1990). The Somatosensory Amplification Scale and its relationship to hypochondriasis. Journal of Psychiatric Research, 24(4), 323-334.

Blushield (n.d.). Blushield - Active EMF Protection from New Zealand - Blushield Active EMF Protection. Retrieved January 8, 2015, from http://www.blushield-eu. com/?gclid=Cj0KEQiA8rilBRDZu_G8hszXraoBEiQABlB9YwvoeGzWeAjmT-jwl83-Ew VuJ10188aGRJOheO6oKIYaApuL8P8HAQ

Claassen, L., Smid, T., Woudenberg, F., \& Timmermans, D.R.M. (2012). Media coverage on electromagnetic fields and health: Content analysis of Dutch newspaper articles and websites. Health, Risk \& Society, 14(7-8), 681-696.

Cohen, S. (1972). Folk devils and moral panics: the creation of the mods and rockers. Oxford: Blackwell 
Eldridge-Thomas, B., \& Rubin, G. J. (2013). Idiopathic environmental intolerance attributed to electromagnetic fields: A content analysis of British newspaper reports. PLoS ONE, 8(6), e65713. http:/ / doi.org/10.1371/journal.pone.0065713

Elvers, H.-D., Jandrig, B., Grummich, K., \& Tannert, C. (2009). Mobile phones and health: Media coverage study of German newspapers on possible adverse health effects of mobile phone use. Health, Risk \& Society, 11(2), 165-179.

Epstein, S. (2014). Cognitive-experiential theory. Oxford: Oxford University Press

Filipkowski, K.B., Smyth, J.M., Rutchick, A.M., Santuzzi, A.M., Adya, M., Petrie, K.J., \& Kaptein, A.A. (2010). Do healthy people worry? Modern health worries, subjective health complaints, perceived health, and health care utilization. International Journal of Behavioral Medicine, 17(3), 182-188.

Freyler, A., Kőhegyi, Z., Köteles, F., Kökönyei, G., \& Bárdos, G. (2013). Modern health worries, subjective somatic symptoms, somatosensory amplification, and health anxiety in adolescents. Journal of Health Psychology, 18(6), 773-781.

Furnham, A. (2007). Are modern health worries, personality and attitudes to science associated with the use of complementary and alternative medicine? British Journal of Health Psychology, 12(2), 229-243.

Goode, E., \& Ben-Yehuda, N. (2009). Moral panics: The social construction of deviance (2nd edition). Chichester, Wiley-Blackwell

Gyollai, Á., Simor, P., Köteles, F., \& Demetrovics, Z. (2011). The psychometric properties of the Hungarian version of the original and short form of Positive and Negative Affect Schedule (PANAS). Neuropsychopharmacologia Hungarica, 13(2), 73-79.

Haenen, M.A., Schmidi, A.J., Schoenmakers, M., \& van den Hout, M.A. (1997). Tactual sensitivity in hypochondriasis. Psychotherapy and Psychosomatics, 66(3), 128-132.

Hamoni (n.d.). Der Hamoni ${ }^{\circledR}$ Harmonisierer - Der Hochwirksame Schutz vor Elektrosmog, Erdstrahlen und Wasseradern. Retrieved January 8, 2015, from http://www. elektrosmoghilfe.com/

Hyland, M.E., Lewith, G.T., \& Westoby, C. (2003). Developing a measure of attitudes: the holistic complementary and alternative medicine questionnaire. Complementary Therapies in Medicine, 11(1), 33-38.

ICNIRP. (2003). Exposure to static and low frequency electromagnetic fields, biological effects and health consequences $(0-100 \mathrm{kHz})$. Munich: International Commission on Non-Ionizing Radiation Protection

ICNIRP. (2010). Guidelines for limiting exposure to time-varying electric and magnetic fields (1Hz-100kHz). Health Physics, 99(6), 818-836.

Indregard, A.-M.R., Ihlebæk, C.M., \& Eriksen, H.R. (2013). Modern health worries, subjective health complaints, health care utilization, and sick leave in the Norwegian working population. International Journal of Behavioral Medicine, 20(3), 371-377.

Jeswani, M., \& Furnham, A. (2010). Are modern health worries, environmental concerns, or paranormal beliefs associated with perceptions of the effectiveness of complementary and alternative medicine? British Journal of Health Psychology, 15(3), 599-609.

Kasperson, J.X., Kasperson, R.E., Pidgeon, N., \& Slovic, P. (2003). The social amplification of risk: assessing fifteen years of research and theory. In N. Pidgeon, R.E. Kasperson, \& P. Slovic (Eds.), The social amplification of risk (13-46). Cambridge: Cambridge University Press

Kasperson, R.E., Renn, O., Slovic, P., Brown, H.S., Emel, J., Goble, R., et al. (1988). The social amplification of risk: a conceptual framework. Risk Analysis, 8(2), 177-187. 
Köteles, F. (2014). A Holisztikus Természetgyógyászat Kérdőív magyar változatának (HCAMQ-H) pszichometriai vizsgálata [Psychometric evaluation of the Hungarian version of the Holistic Complementary and Alternative Medicine Questionnaire (HCAMQ-H)]. Mentálhigiéné és Pszichoszomatika, 15(1), 49-65.

Köteles, F., Bárány, E., Varsányi, P., \& Bárdos, G. (2012). Are modern health worries associated with somatosensory amplification, environmental attribution style, and commitment to complementary and alternative medicine? Scandinavian Journal of Psychology, 53(2), 144-149.

Köteles, F., Freyler, A., Kökönyei, G., \& Bárdos, G. (2015). Family background of modern health worries, somatosensory amplification, and health anxiety: A questionnaire study. Journal of Health Psychology, 20(12), 1549-1557.

Köteles, F., Gémes, H., Papp, G., Túróczi, P., Pásztor, A., Freyler, A., et al. (2009). A Szomatoszenzoros Amplifikáció Skála (SSAS) magyar változatának validálása [Validation of the Hungarian version of the Somatosensory Amplification Scale (SSAS)]. Mentálhigiéné és Pszichoszomatika, 10(4), 321-335.

Köteles, F., \& Simor, P. (2014a). Modern health worries, somatosensory amplification, health anxiety, and well-being. A Cross-sectional Study. European Journal of Mental Health, 9(1), 20-33.

Köteles, F., \& Simor, P. (2014b). Somatic symptoms and holistic thinking as major dimensions behind modern health worries. International Journal of Behavioral Medicine, 21(5), 869-876.

Köteles, F., Simor, P., \& Bárdos, G. (2011). A Rövidített Egészségszorongás Kérdőív (SHAI) magyar verziójának kérdőíves validálása és pszichometriai értékelése [Validation and psychometric evaluation of the Hungarian version of the Short Health Anxiety Inventory (SHAI)]. Mentálhigiéné és Pszichoszomatika, 12(3), 191-213.

Köteles, F., Simor, P., Czető, M., Sárog, N., \& Szemerszky, R. (n.d.). Modern health worries - the dark side of spirituality? Unpublished Manuscript.

Köteles, F., Szemerszky, R., Freyler, A., \& Bárdos, G. (2011). Somatosensory amplification as a possible source of subjective symptoms behind modern health worries. Scandinavian Journal of Psychology, 52(2), 174-178.

Köteles, F., Szemerszky, R., Gubányi, M., Körmendi, J., Szekrényesi, C., Lloyd, R., et al. (2013). Idiopathic environmental intolerance attributed to electromagnetic fields (IEIEMF) and electrosensibility (ES) - Are they connected? International Journal of Hygiene and Environmental Health, 216(3), 362-370.

Kroenke, K., Spitzer, R.L., \& Williams, J.B.W. (2002). The PHQ-15: validity of a new measure for evaluating the severity of somatic symptoms. Psychosomatic Medicine, 64(2), 258-266.

Litmanen, T., \& Tuikkanen, A. (2008). Global sense of risk: Media reporting on scientific studies and potential risks of mobile phones. Journal of Research and Practice in Information Technology, 40(2), 71-90.

Ozakinci, G., Boratav, H.B., \& Mora, P.A. (2011). Modern health worries, health care utilization, and symptom reporting: a cross-cultural comparison. Behavioral Medicine (Washington, D.C.), 37(2), 35-41.

Petrie, K.J., Sivertsen, B., Hysing, M., Broadbent, E., Moss-Morris, R., Eriksen, H.R., \& Ursin, H. (2001). Thoroughly modern worries: the relationship of worries about modernity to reported symptoms, health and medical care utilization. Journal of Psychosomatic Research, 51(1), 395-401.

Petrie, K. J., \& Wessely, S. (2002). Modern worries, new technology, and medicine. BMJ (Clinical Research Ed.), 324(7339), 690-691.

Repacholi, M. (2012). Concern that "EMF" magnetic fields from power lines cause cancer. The Science of the Total Environment, 426, 454-458. 
Rief, W., Glaesmer, H., Baehr, V., Broadbent, E., Brähler, E., \& Petrie, K.J. (2012). The relationship of modern health worries to depression, symptom reporting and quality of life in a general population survey. Journal of Psychosomatic Research, 72(4), 318-320.

Röösli, M., Frei, P., Mohler, E., \& Hug, K. (2010). Systematic review on the health effects of exposure to radiofrequency electromagnetic fields from mobile phone base stations. Bulletin of the World Health Organization, 88(12), 887-896.

Rubin, G.J., Hillert, L., Nieto-Hernandez, R., van Rongen, E., \& Oftedal, G. (2011). Do people with idiopathic environmental intolerance attributed to electromagnetic fields display physiological effects when exposed to electromagnetic fields? A systematic review of provocation studies. Bioelectromagnetics, 32(8), 593-609.

Rubin, G.J., Nieto-Hernandez, R., \& Wessely, S. (2010). Idiopathic environmental intolerance attributed to electromagnetic fields (formerly "electromagnetic hypersensitivity"): An updated systematic review of provocation studies. Bioelectromagnetics, 31(1), 1-11.

Salkovskis, P.M., Rimes, K.A., Warwick, H.M. C., \& Clark, D.M. (2002). The Health Anxiety Inventory: development and validation of scales for the measurement of health anxiety and hypochondriasis. Psychological Medicine, 32(5), 843-853.

Sensory Perspective (n.d.). The Electrosmog Detector MANUFACTURER | Detect \& Protect from Phone and Wi-Fi Radiation. Retrieved January 8, 2015, from http:/ / www.detectprotect.com $/ \mathrm{k} /$

Speckens, A.E., Spinhoven, P., Sloekers, P.P., Bolk, J.H., \& van Hemert, A.M. (1996). A validation study of the Whitely Index, the Illness Attitude Scales, and the Somatosensory Amplification Scale in general medical and general practice patients. Journal of Psychosomatic Research, 40(1), 95-104.

Strait, L., \& Furnham, A. (2012). The effects of modern health worries and psychological distress on complementary medicine use by breast cancer patients. Journal of Clinical Research E Bioethics, 3(1), 1000126. http:/ / doi.org/10.4172/2155-9627.1000126

Swiss Harmony (n.d.). Electrosmog - living with it and staying healthy. Retrieved January 8, 2015, from http://swissharmony.com/en/electrosmog-living-with-it-and-stayinghealthy

Szemerszky, R., Gubányi, M., Árvai, D., Dömötör, Z., \& Köteles, F. (2015). Is there a connection between electrosensitivity and electrosensibility? A replication study. International Journal of Behavioral Medicine, 22(6), 755-763.

Szemerszky, R., Köteles, F., Lihi, R., \& Bárdos, G. (2010). Polluted places or polluted minds? An experimental sham-exposure study on background psychological factors of symptom formation in "Idiophatic Environmental Intolerance attributed to electromagnetic fields". International Journal of Hygiene and Environmental Health, 213(5), 387-394.

Thompson, E.R. (2007). Development and validation of an internationally reliable shortform of the Positive and Negative Affect Schedule (PANAS). Journal of Cross-Cultural Psychology, 38(2), 227-242.

Vilella-Vila, M., \& Costa-Font, J. (2008). Press media reporting effects on risk perceptions and attitudes towards genetically modified (GM) food. The Journal of Socio-Economics, 37(5), 2095-2106.

Wahlberg, A.A.F., \& Sjoberg, L. (2000). Risk perception and the media. Journal of Risk Research, 3(1), 31-50.

Watson, D., Clark, L.A., \& Tellegen, A. (1988). Development and validation of brief measures of positive and negative affect: The PANAS scales. Journal of Personality and Social Psychology, 54(6), 1063-1070. 
Wheeler, P., \& Hyland, M.E. (2008). The development of a scale to measure the experience of spiritual connection and the correlation between this experience and values. Spirituality and Health International, 9(4), 193-217.

WHO (2006). Electromagnetic fields and public health. Base stations and wireless technologies. Backgrounder. Retrieved August 5, 2015, from http://www.who.int/peh-emf/publica tions/facts/fs304/en/

WHO (2007). Electromagnetic fields and public health. Exposure to extremely low frequency fields. Backgrounder. Retrieved August 5, 2015, from http://www.who.int/peh-emf/publica tions/facts/fs322/en/

WHO (2014). Electromagnetic fields and public health: mobile phones. Fact sheet $N^{\circ} 193$. Retrieved August 5, 2015, from http://www.who.int/mediacentre/factsheets/fs193/en/

Witthöft, M., \& Rubin, G.J. (2013). Are media warnings about the adverse health effects of modern life self-fulfilling? An experimental study on idiopathic environmental intolerance attributed to electromagnetic fields (IEI-EMF). Journal of Psychosomatic Research, 74(3), 206-212.

Wyshak, G., Barsky, A.J., \& Klerman, G.L. (1991). Comparison of psychiatric screening tests in a general medical setting using ROC analysis. Medical Care, 29(8), 775-785.

\section{Acknowledgements}

This research was supported by the Hungarian National Scientific Research Fund (OTKA K 109549).

\section{Authors' contribution}

Ferenc Köteles contributed to conception and design of the study, data analysis and interpretation, and drafting the article. Eszter Tarján participated in development of hypotheses, recruitment of participants, and data acquisition. Tímea Berkes contributed to data acquisition, and drafting and revising of the paper.

\section{Conflict of Interests Statement}

The authors declare that they have no conflict of interest. 


\title{
Mesterséges aggodalmak. Egy hirdetés modernkori egészségféltésre és szimpatikus aktivációra gyakorolt hatása
}

\author{
KÖTELES FERENC - TARJÁN ESZTER - BERKES TÍMEA
}

Elméleti háttér: Számos cég kínál káros környezeti hatásoktól védőnek beállított termékeket. E termékek kereskedelmi hirdetéseit eleve a kockázatészlelés és az aggodalmaskodás maximalizálására tervezik, ezáltal kedvezőtlen hatást gyakorolhatnak a mindennapi pszichológiai múködésre. Emellett fokozhatják a különböző környezeti tényezők egészségkárosító hatásaival kapcsolatos társadalmi szintú aggodalmakat is.

Cél: Egy kereskedelmi hirdetés aggodalmaskodásra és szimpatikus aktivációra gyakorolt hatásának mérése.

Módszerek: 100 fiatal felnőtt töltött ki olyan pszichológiai konstruktumokat mérő kérdőíveket, amelyek korábbi kutatási eredmények alapján kapcsolódtak a modernkori egészségféltéshez (szomatoszenzoros amplifikáció, egészségszorongás, testi tünetek, a természetgyógyászati módszerek hatásosságával kapcsolatos hiedelmek, holisztikus egészségszemlélet, spiritualitás). A résztvevők ezután az elektromágneses sugárzás kockázatait eltúlzottan bemutató filmet vagy egy kontrollfilmet néztek meg. A szimpatikus aktiváció (szívfrekvencia) az intervenció előtt és után, az aggodalmaskodás (a modernkori egészségféltés kérdőív Sugárzás alskálája) az intervenció előtt, után, és három héttel később került mérésre.

Eredmények: A hirdetés a kontrollfilmhez viszonyítva akut szívfrekvencia-növekedést okozott $(\mathrm{t}(98)=4,122, \mathrm{p}<0,001)$. Az aggodalmaskodás változását tesztelő kétszempontos vegyes varianciaanalízis szignifikáns csoport $\times$ idó interakciót $(F(2,98)=3,455 ; p=0,034)$ jelzett. A post hoc elemzés eredményei szerint a kontrollcsoport nem mutatott eltérést az alapszinttől. A hirdetést néző csoportban ugyanakkor az intervenciót követő mindkét mérési időpontban szignifikánsan $(\mathrm{p}<0,05)$ magasabb aggodalmaskodási szintet mértünk. Az aggodalmaskodásban az intervenció hatására bekövetkező akut változás nem kapcsolódott egyetlen kérdőívvel mért konstruktumhoz sem.

Következtetések: Egyes egészségvédő termékek kereskedelmi hirdetései szerepet játszhatnak a modernkori egészségféltés kialakulásában és fenntartásában. Tágabb perspektívából nézve e hirdetések fokozhatják a kockázat társadalmi amplifikációját, és akár egy morális pánik kialakulásához is hozzájárulhatnak.

Kulcsszavak: kockázatészlelés, közegészség, modernkori egészségféltés, morális pánik 